\title{
ADDITIONAL FIGURES IN ADY ENDRE'S POEM: A MAGYAR UGARON AND IN ITS ENGLISH TRANSLATIONS: THE MAGYAR FALLOW BY NYERGES ANTON AND ON THE HUNGARIAN FALLOW BY BERNARD ADAMS
}

\author{
TIMEA KISS \\ Kistimcsi86@gmail.com \\ Selye János University, Komárno, Slovakia
}

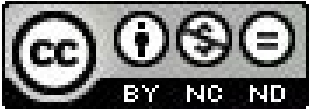

\begin{abstract}
My paper examines the figures of speech in English translations of Ady's poem. The main organizers in Ady's texts are repetition, parallelism, antithesis and other figures. The connection between these figures is an important component of his style. I examine whether the translations are showing these figures, and if so, what their function is. The paper mostly concentrates on repetition in the translations. An analysis of one poem by Ady is presented through the translated texts.
\end{abstract}

Key words: figures, translation, repetition, additional figures of speech, variants

\section{INTRODUCTION}

This paper examines the system of stylistic figures in poems by Endre Ady and the English translations of the same poem, tries to present how these figures appear in the translations. The aim of this work is to help to identify the function of figures of speech in these texts.

The main organizers in Ady's texts are repetition, parallelism, antithesis and other figures. The connection of these figures is an important component of his style. I examine whether the translations show these figures, and if so, what their function is. The paper mostly concentrates on repetitions in the translations. An analysis of one poem by Ady is presented through the translated texts and compared the source with the target texts. And I examine how the style of the translator influences the style of the original version and how these changes influence the figures and their functions.

To compare the source and target texts I have chosen the poem A magyar Ugaron. While working on my $\mathrm{PhD}$ thesis I am currently analyzing Ady's poetry of his early years and thus I have chosen this verse from volume Új versek (New Songs). Poems from this period of Ady can be difficult to understand for the translators, because his scourging patriotism and ambivalence of his feelings come to the front. In my work I show how Anton Nyerges and Bernard Adams struggled with the topic of Hungarian fallow.

There have been several efforts made to translate Ady's poems. But to precisely transfer the atmosphere, the music and sense of these verses is really difficult. One of his specialties is to quickly enlighten and enormously show the situation in his 
poems. His symbolism is luscious. They come from the world behind as they were just grown out from the soil. Ady is everything and in the same time opposite of everything. This is why his poetry is so mythical. (Lukács, 1977, cited by: Joó, 2009).

\section{ACADEMIC BACKGROUND}

Translation is a kind of traveling between texts and this movement necessarily comes with changes, which deeply re-structuralizes the semantic and pragmatic meaning of the source text (Lörincz, 2007, p. 119). We can see this in the analysis below. To recreate the stylistic figures of speech in poetic texts is not easy, especially in Ady's poetry. The music of a Hungarian poem differs from other languages of the world. The structural and logical differences between languages also encumber the translation. It seems the translations of Ady have the feeling of the pre-Ady's period. Also Kosztolányi points out about the context of history of Ady's specific style, that a style cannot be exactly copied to another language. And the translator only wishes to symbolize Ady's language which infact has no exact equivalent. If the translator would like to reach this then he would need a Csokonai, Vörösmarty and Arany-Petófi period in his own culture (Szúcs, 2007, p. 155). The two target texts are more explicit than the original and the translator reaches from thought to grammatical form in a more complicated way. The translator - to help the communication - interprets, explains to make the information process easier for the target readers (Klaudy, 2007, p. 158). The translator expresses something more open, speaks clearly or sometimes uses more words in the target text compared to the source text (Klaudy, 2007, p. 159). Equivalency is another matter: the accuracy of the translations, the sameness with the original text. There are different opinions about this in literary pieces but the fact that literary translations cannot be kept as copies of the original text is widely accepted. As long as the complex equivalency appears the modification in levels and types of source are acceptable in the target text (Lörincz, 2007, p. 49). But in case of Ady the paradox of impossibility of translation comes into question. It was declared by Ignotus that there is no translation only a poet who some day writes how deeply he is in love, another time writes a poem which he read in a foreign language (Ignotus, cited by: Józan, 2009, p. 161). The phrasal and contextual complexity, the complexity of the language and thoughts have a role in creating adequate target texts. So the task of the translator is to fulfill the role of the transmitter despite the differences between the cultures and languages of the world (Simigné Fenyő 2006, p. 99). It is important to examine also the role or function of each translation in target context and besides giving back the invariant summary what other message is carried by the translation (Simigné Fenyő, 2006, p. 98). Especially in case of Ady's poetry where the questions of translatability are still open and are often topics of discussions.

\section{FIGURES IN THE POEM}

The additional figures (adiectio) are one of the four fundamental operations, or categories of speech, governing the formation of all figures of speech. These additional figures are dominant in this poem: parallelism, antithesis, anaphora, 
epanalepsis, epistrophe and climax. To help the understanding of these figures in the analysis see the definitions below:

- Parallelism: The use of similar structures in two or more clauses.

- Antithesis: Juxtaposition of opposing or contrasting ideas.

- Anaphora: Repetition of the same word or group of words at the beginning of successive clauses.

- Epanalepsis: Repetition of the initial word or words of a clause or sentence at the end of the clause or sentence.

- Epistrophe: Repetition of the same word or phrase at the end of successive clauses.

- Climax: Arrangement of words in order of increasing importance.

\section{FUNCTIONAL AND STYLISTIC METHODS USED FOR PARALLEL CORPUS ANALYSIS}

The additional figures are examined in A magyar Ugaron and in its two English translations. These three texts are compared to gain an understanding of how the translators re-interpreted the verse. If we look at the title of the two target texts we can see they significantly differ from each other. Only a few words are the same in the two target texts. The version of Bernard Adams aspires to keep the atmosphere of the verse. Anton Nyerges rather keeps the lexical and formal elements of the original.

The poem A magyar Ugaron is the cadence and gives the title of the cycle. The title of the version published in Budapesti Napló in 1905 was A magyar Ugar without the adverb of place. The translators also use these variants of title. Adams uses the version from 1906: A magyar Ugaron. While Nyerges takes the one published in Budapesti Napló without translating the word "magyar" (Hungarian).

In the first strophe the narrative voice places itself in the imagined space; places itself on the fallow (Elvadult tájon gázolok). The verb in the first person singular form wade (gázolok) strengthens the placement on the fallow. This is an antithesis because to wade expresses an intensive movement on the passive, motionless, barren soil. The title and the last sentence of the first verse create an epanalepsis: A magyar Ugaron, Ez a magyar Ugar. In between we can find enumerations which describe the fallow: Unweeded land, rank soil, wild meadow, weed, Hungarian millet. The first person singular verbs in present tense give more stress on the presence of the narrative voice: wade, know. Demonstrative pronouns: ez, ezt create an anaphora: ezt a vad mezöt ismerem, / ez a magyar Ugar. The English translations fairly differ from this. Although the narrative voice places itself on the fallow in the target texts but the intensity of the word wade is softened to walk by both of the translators. The unweeded land in Nyerges's text turns to meadows run to weed, and in Adam's text it turns to land fertile of old. With this the antithesis becomes less significant. In Nyerges's variant the epanalepsis can be found: The magyar fallow, this is the Magyar fallow. The other target text makes meaningful changes not just in the form but in the substance on the source text: I walk a land, fertile of old, / But now grown wild with millet-grass and tares. / This fallow field is Hungary, / For which none cares. Original version: I wade on a wild meadow, Lush ancient field, weeds, Hungarian 
millet, I know this wild field, this is the Hungarian fallow. The enumeration inside the epanalepsis cannot be found in the target text. In Nyerges's translation besides the enumeration we can find verbs stressing narrative voice: I walk on meadows run to weed, / on fields of burdock and of mallow, / I know this rank and ancient ground - / this is the Magyar fallow. In Adams's variant the third line is completely changed and switched with the fourth line: This fallow field is Hungary, / For which none cares. In this way the repetition of the demonstrative pronouns is erased. At Nyerges we can find the pronouns but as invariant and not as anaphoric repetition: I know this rank and ancient ground - / this is the Magyar fallow.

In the second verse adversative thoughts appear. Creating semantic reverse with wild meadow, lush, ancient field the symbols of holy humus and virgin land appear: I wade on a wild meadow, lush ancient field, weeds, Hungarian millet, I know this wild field, this is the Hungarian fallow. I bow down to the holy humus, in this virgin land something is chewing.

The differences between the texts are not as significant as in the first verse. Adams's translation: Low to the sacred soil I bend, / Some baneful things its purity now sours. / Alas, you skyward-stretching weeds, / Are there no flowers? Nyerges's translation: I bow down to the sacred soil; / this virgin ground is gnawed, I fear. / Hey, skyward groping seedy weeds, / are there no flowers here? If we look at the lexical meaning of the words we can find the words of the original poem. But the antithesis in the translations cannot be equivalent with the original, on the basis of emotionless and disappeared adjectives in the first verse. The holy humus is turned to sacred soil in both of the translations. But the additional meaning of the word humus - which means rotten animals and plants - does not come in the word soil. So the antithesis is not strengthened in the adjectival locution. The second line of the second verse in the original text has been translated differently. Nyerges's variant gives back the lexical meaning correctly but is grammatically modified: the active grammatical construction turns into passive and thereby causes temporal change in the timeline of the poem: this virgin ground is gnawed, I fear. The phrase I fear is added to keep the structure of rhyme - fear-hear. But by inserting the personal pronoun and verb (I fear) a variational epanalepsis appears in Nyerges's text. The second verse still keeps the narrative voice stressed while in the original text the narrative voice is slowly pushed into background, which has an impact on the interpretation. In Adams's text this line lexically differs from the original: Some baneful thing its purity now sours. While grammatically it remains active and present. The subject with the added adjective in the target texts causes semantic change.

The antithesis appears in the second half of the verse in the source text: I bow down to the holy humus, / In this virgin land something is chewing, / Hey, sky-high weeds, / So is there no flower here. The holy humus and virgin land are in contrast with sky-high weeds. The something is chewing includes the worms in itself, so it creates semantical contrast with the virgin and holy adjectival constructions.

The second half of the second verse is transferred equivalently by both target texts. Nyerges: Hey, skyward groping seedy weeds, / are there no flowers here? Adams: Alas, you skyward-stretching weeds, Are there no flowers? The only difference in Nyerges's target text is that in place of the present participle nyúló (stretching) he used 
skyward groping. This keeps back the activity of the weeds and gives the seedy adjective to weeds. Using seedy weeds he tries to give back the sound of giz-gazok from the original poem. The translation by Adams misses this intention.

Between the first and second verse of the source text we can find antithesis. But we can also find this figure in the second verse creating parallelism between these strophes which ends with a question opening with the Hey interjection. We can find the mentioned figures in both target texts but on account of the changes and the ellipsis the antithesis is not so deep as in Ady's poem. Nor is the interjection missing but while Nyerges's version is formally equivalent with the Hungarian: Hey/Hej; Adams has chosen Alas which means haj or ó. The question is almost the same as in the source: Are there no flowers? / Are there no flowers here? Nyerges keeps the demonstrative pronoun (here) with this following the original technique of rhyme (Rág / virág - fear / hear). The lines of Adams's version rhyme well too but the semantic meaning changes: the lack of the demonstrative pronoun pushes the presence of the narrative voice on the fallow back into the background. To compensate this, in the translation the narrative voice speaks to the weeds: Alas, you skyward-stretching weeds.

In the third strophe of the original poem there is a change. The active narrative voice retires and the fallow becomes active: vine encircles, the weed pulls down, put to sleep, laughing wind whisking, while the narrative voice only peeps at the sleeping soul of the ground and is dazed by scent of flowers. We can determine that the narrative voice is dominant in the first two while the fallow is dominant in the last two verses. So antithesis makes a tension between these strophes. We can find other figures in the closing verse, such as enumeration: the weed, the Hungarian millet, the weed pulls down, put to sleep, covers. The climax emphasizes the victory of the fallow over the narrative voice. This is followed by the laughing wind above the mighty fallow. In the target texts we cannot feel this retirement of the narrative voice. Nyerges: While I look at the slumbering earth, / the twisting vines encircle me, / and scents of long dead flowers steep / my senses amorously. Adams: The spirit of the land sleeps on. / I watch. About me tendrils sinuate. / The cherished scents of flowers long dead / Intoxicate. The antithesis remains but the complex picture is changing in the target texts. In Adams's variant the narrative voice is stressed by the first person singular pronouns $(I, m e, m y)$. The original message is damaged because the translator changed the verbal subject peep to look and the adjective past to long dead. The lexical meaning is equivalent, but as a result of pragmatic modification the atmosphere of the antithesis between the narrative voice and the fallow is moderated. The closing strophe in Adams's target variant is almost equivalent with the source: Silence. The millet/grass and tares / Drag me down, stupefy, envelop, and / A mocking wind wafts by above / Our fallow land. Besides the grammatical and lexical changes we can find the figures of climax and enumeration. To use the possessive pronoun our: epenthesis appears and this stresses the proper place of the narrative voice. But detracting the adjective big and by use of the possessive pronoun (our) the victory of the fallow is not clear. Since the narrative voice puts itself willingly onto the fallow, become one with it, causing semantical modification in the entire poem too. The narrative voice is present in the closing strophe of Nyerges's variant: Silence. I am dragged down and roofed/and lulled in burdock and in mallow. / A mocking wind flies 
whisking by / above the mighty fallow. Nyerges makes a deeper grammatical change in his variant. He turns the active verbs of the original text to passive, with this he features the narrative voice and the active subject has become the adverb of place. Figures of climax and enumeration also appear in the target text, but the lexical meaning significantly changes (Not the weed that drags down, but the narrative voice is dragged down to the weed by someone). With the pragmatic changes questions of interpretation occur. The conflict between the fallow and the narrative voice is not clear, the atmosphere of the Hungarian version is expressed by word mocking (in place of laughing), but antithesis between them is not stressed so much. The qualificative adjective big is replaced by the synonym mighty which contains a semantic extra (connotations of mighty: strong, great, extraordinary). The translator wanted to disambiguate the victory of the fallow even if the narrative voice is present in the whole poem.

The last line of the opening verse is repeated at the end of the poem: this is the Hungarian fallow; above the big fallow. The epanalepsis is closed. The poem is rich in figures realized in adjectival construction: wild landscape, lush ancient field, wild meadow, holy humus, virgin land, sky-high weeds, wild vines, sleeping soul, flowers of the past, laughing wind. The function of these figures keep up the appearance of visionary landscape poetry and to create the "falling composition": wade, know, bow down, peep, intoxicate, to daze, pull down, cover. The laughing wind is whisking above the big fallow. The "falling composition" is based on the oppositional phrases up and down (vertical and horizontal). First the narrative voice is active (walk, bow, look) later it is dazed by flowers and at the end it gets below the fallow (envelop). In the target variants the majority of the figures of adjectival construction are replaced with paraphrases. Even with these lexical and semantic modifications we can find the "falling composition": walk - know - bend / bow - watch - intoxicate / steep - drag down - roof/envelope, mocking wind - mighty fallow. The vertical opposite of up and down is equivalent in each of the target variants, but the antithesis between the narrative voice and the fallow is modified by the more powerful presence of the narrative voice. This influences the basic structure of the whole poem.

\section{CONCLUSION}

The structure of the poem is based on an antithesis joined with parallelism. Joint figures are created in these parallelisms with many other figures like antithesis, climax, rhetorical question and the anticlimax which results the "falling composition". The effect of complex figure of visional allegory which weaves through the whole poem is weakened in the target texts because of the grammatical, lexical and semantic changes. The poetical vision which capitalizes the Fallow as a metonymy is extracted by Adams (this fallow field is Hungary) but with this change its function is destroyed at the same time. The vision at Nyerges remains, but instead of the fallow he stresses the word Hungarian. Adams also uses the one time capitalization in his closing line of the poem: Our fallow Land. By using this possessive pronoun the metonymy is destroyed again. In the English translations the dual meaning of the motif fallow (system of dependence and lonely feeling of crisis) only glimmers. 
The improvement in the methods of translation and the loss of importance in translation of classics are both responsible for the fact that Ady's life-work is still waiting for a complex and high poetical quality interpretation.

\section{PRIMARY SOURCES}

Ady Endre összes versei [All poems of Ady Endre] (1998). Budapest: Osiris Kiadó.

Nyerges, A. (n.d.). The magyar fallow. Retrieved July 27, 2012 from: http://www.babelmatrix.org/ works/hu/Ady_Endre/A_magyar_Ugaron/en/1837-The_magyar_fallow

Adams, B. (n.d.). On the Hungarian fallow. Retrieved July 27, 2012 from: www.hlo.hu/.../ poem_of_the_month_endre_ady_on_the_hungarian_

\section{REFERENCES}

Haas, L. (2005). A Vén cigány franciául [French version of The Vén cigány]. In: I. Józan, M. Szegedy-Maszák, A „,boldog Bábel” [The happy Babel] (pp. 273 - 293). Budapest: Gondolat kiadó..

Joó, E. (2009). Franyó Zoltán német Ady-fordításai [German translations of Ady by Zoltán Franyó]. In: Alkalmazott nyelvészeti közlemények, 111 - 119.

Józan, I. (2009). A fordítás lehetetlensége. [Impossibility of translation]. In: Mü, fordítás, történet [Opus, translation, history] (pp. 160 - 169). Budapest: Balassi Kiadó.

Lőrincz, J. (2007). Magyar versek orosz és angol fordításban [Russian and English translations of Hungarian poems]. In: Kultúrák párbeszéde [Dialogue of cultures] (pp. 101 - 143). Eger: Líceum kiadó.

Lőrincz, J. (2007). A szépirodalmi szöveg és fordított szövegvariánsának egyenértékúségi viszonya. [Equivalency of literary texts and its translated variants]. In: Kultúrák párbeszéde [Dialogue of cultures] (pp. 47 - 49). Eger: Líceum kiadó.

Szúcs, T. (2007). A magyar vers kettős nyelvi tükörben [The Hungarian poem in bilingual mirror]. Budapest: Tinta Könyvkiadó.

Király, I.(1972). Ady Endre. Budapest: Magvető Kiadó.

Klaudy, K. (2007). Az explicitáció hipotéziséról [About the hypothesis of explicitation]. In: Nyelv és fordítás [Language and translation] (pp. 155 - 169). Budapest: Tinta könyvkiadó.

Popovič, A. (1980). A müfordítás elmélete [The theory of translation]. Bratislava: Madách.

Pusztai-Varga, I. (2010). A nyelvi kifejtés típusai finn versek angol és magyar fordításában [Types of linguistic explanations in English and Hungarian translations of Finnsih poems]. In: Nyelvek találkozása a fordításban [Language dialogues in translations] (pp. 135 - 158). Budapest: ELTE kiadó.

Simigné Fenyő, S. (2006). A fordítás mint kulturális transzfer [The translation as a cultural transfer] In: A forditás mint közvetítés [The translation as a transfer] (pp. 98 - 115). Miskolc.

Szabó, G. Z., Szörényi, L. (1988). Kis magyar retorika [Small Hungarian rhetoric]. Budapest: Tankönyvkiadó.

\section{Ady Endre}

\section{A MAGYAR UGARON}

Elvadult tájon gázolok:

Ős, buja földön dudva, muhar.

Ezt a vad mezót ismerem,

Ez a magyar Ugar.

Lehajlok a szent humusig:

E szúzi földön valami rág.

Hej, égig-nyúló giz-gazok,

Hát nincsen itt virág?

Vad indák gyûrúznek körül,

Míg a föld alvó lelkét lesem,

Régmult virágok illata 
Bódít szerelmesen.

Csönd van. A dudva, a muhar,

A gaz lehúz, altat, befed

S egy kacagó szél suhan el

A magyar Ugar felett.

Nyerges Anton

\section{THE MAGYAR FALLOW}

I walk on meadows run to weed, on fields of burdock and of mallow. I know this rank and ancient ground this is the Magyar fallow.

I bow down to the sacred soil;

this virgin ground is gnawed, I fear. Hey, skyward groping seedy weeds, are there no flowers here?

While I look at the slumbering earth, the twisting vines encircle me, and scents of long dead flowers steep my senses amorously.

Silence. I am dragged down and roofed and lulled in burdock and in mallow. A mocking wind flies whisking by above the mighty fallow.

\section{Bernard Adams}

\section{ON THE HUNGARIAN FALLOW}

I walk a land, fertile of old,

But now grown wild with millet-grass and tares.

This fallow field is Hungary,

For which none cares.

Low to the sacred soil I bend, Some baneful thing its purity now sours.

Alas, you skyward-stretching weeds, Are there no flowers?

The spirit of the land sleeps on.

I watch. About me tendrils sinuate.

The cherished scents of flowers long dead Intoxicate.

Silence. The millet-grass and tares Drag me down, stupefy, envelop, and A mocking wind wafts by above Our fallow Land. 